\title{
A20 deficiency sensitizes pancreatic beta cells to cytokine-induced apoptosis in vitro but does not influence type 1 diabetes development in vivo
}

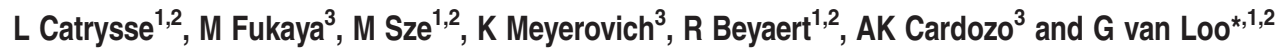 \\ Cell Death and Disease (2015) 6, e1918; doi:10.1038/cddis.2015.301; published online 15 October 2015
}

\section{Dear Editor,}

Type 1 diabetes mellitus (T1D) is an autoimmune disease characterized by the infiltration of inflammatory cells into the pancreatic islets of Langerhans, followed by the selective destruction of insulin-producing $\beta$-cells, resulting in hyperglycemia. One of the mechanisms causing $\beta$-cell death is the intra-islet release of inflammatory mediators such as interleukin-1 $\beta$ (IL-1 $\beta$ ), tumor necrosis factor (TNF) and interferon- $\gamma$ (IFN- $\gamma$ ) by activated immune cells. ${ }^{1}$ Hence, the transcription factor $\mathrm{NF}-\kappa \mathrm{B}$ promotes pro-inflammatory and pro-apoptotic responses in $\beta$-cells on cytokine exposure. A transgenic mouse line in which NF- $\kappa$ B activation is attenuated specifically in $\beta$-cells conferred nearly complete protection against multiple low dose streptozotocin (MLDSTZ)-induced T1D. ${ }^{2}$ Contrary, mice with constitutively active NF- $K B$ signaling in $\beta$-cells spontaneously develop full-blown immune-mediated diabetes. ${ }^{3}$

The ubiquitin-editing enzyme A20 is a critical negative regulator of NF- $K \mathrm{~B}$ signaling in response to multiple stimuli, including TNF and IL-1. Moreover, A20 can also act as a strong anti-apoptotic protein in specific cell types. ${ }^{4}$ A20 has been identified as the most highly upregulated anti-apoptotic protein in cytokine-stimulated primary islets and insulinoma cell lines. ${ }^{5}$ Consistent with this, overexpression of A20 in islets confers resistance to cytokine-mediated activation of $\mathrm{NF}-\kappa \mathrm{B}$, protecting them from apoptosis in the early posttransplantation period. ${ }^{6}$ Interestingly, not only have NF- $\kappa$ B polymorphisms been identified in patients with $T 1 D,{ }^{7}$ also A20/TNFAIP3 has been identified as a T1D susceptibility locus in humans. ${ }^{8}$ Together, these data suggest an important role for $\mathrm{A} 20$ in $\beta$-cell function and T1D. Therefore, we generated and characterized A20-deficient mice which lack expression of A20 specifically in $\beta$-cells (Supplementary Figure 1A).

We first confirmed the anti-apoptotic function of A20 in $\beta$-cells, as primary islets isolated from $\beta$-cell-specific A20 knockout $\left(\mathrm{A} 2 \mathrm{O}^{\beta-\mathrm{KO}}\right)$ mice were more susceptible to cytokine-induced cell death compared with wild-type islets (Supplementary Figure 1A). As A20 has a crucial role in $\beta$-cell survival in vitro, we next investigated whether A $20^{\beta-K O}$ mice would be more susceptible to diabetes development when compared with wild-type littermates. $\mathrm{A} 2 \mathrm{O}^{\beta-\mathrm{KO}}$ mice aged normally without any evidence of metabolic defects. Phenotypic analysis of $A 20^{\beta-K O}$ mice up to the age of 12 months revealed no pathological signs in the pancreas. $\mathrm{A} 2 \mathrm{O}^{\beta-\mathrm{KO}}$ mice and control littermates were subjected to a model of T1D induced by MLDSTZ, however, both control and $\mathrm{A} 2 \mathrm{O}^{\beta-\mathrm{KO}}$ mice developed a similar hyperglycemia, which was confirmed in a glucose tolerance test (ipGTT) performed 5 weeks after the first STZ injection (Supplementary Figure 1B). Next, we crossed A20 ${ }^{\beta-K O}$ mice with C57BL6-Ins $2^{\text {Akita }} / \mathrm{J}$ mice, which carry a mutation in the insulin Ins2 gene that prevents normal folding and secretion and induces endoplasmic reticulum stress leading to $\beta$-cell death. Mice carrying the Ins $2^{\text {Akita }}$ mutation become hyperglycemic very early in life, however, no differences could be observed in conditions of A20 deficiency in $\beta$ cells. In agreement, ipGTT shows severe and similar defects in insulin secretion in both Ins $2^{\text {Akita }}$ and $A 20^{\beta-K O / A k i t a ~}$ mice (Supplementary Figure $1 \mathrm{C}$ ). Finally, $\mathrm{A} 2 \mathrm{O}^{\beta-\mathrm{KO}}$ mice were backcrossed into a non-obese diabetic genetic background, and glucose levels were measured every week in order to follow diabetes development. Although only $40 \%$ of all mice developed diabetes, no differences could be detected between control and $\mathrm{A} 2 \mathrm{O}^{\beta-\mathrm{KO}}$ mice (Supplementary Figure 1D). In conclusion, A20 deficiency in $\beta$ cells does not affect $\beta$-cell apoptosis nor disease development in vivo.

\section{Conflict of Interest}

The authors declare no conflict of interest.

\begin{abstract}
Acknowledgements. L. Catrysse is a PhD fellow with the 'Instituut voor Innovatie door Wetenschap en Technologie' (IWT). AK. Cardozo is a research associate with the Fonds de la Recherche Scientifique (FNRS)-Belgium. Research in the authors' lab was supported by grants from the FWO, the 'Belgian Foundation against Cancer', the 'Geneeskundige Stichting Koningin Elisabeth', the Charcot Foundation, the GOA and 'Group-ID MRP' of the Ghent University, the Juvenile
\end{abstract}

${ }^{1}$ Inflammation Research Center, Unit of Molecular Signal Transduction in Inflammation, VIB, B-9052 Ghent, Belgium; ${ }^{2}$ Department of Biomedical Molecular Biology, Ghent University, B-9052 Ghent, Belgium and ${ }^{3}$ ULB Center for Diabetes Research, Université Libre de Bruxelles, B-1070 Brussels, Belgium

${ }^{*}$ Corresponding author: G van Loo, Department of Biomedical Molecular Biology, Inflammation Research Center, VIB and Ghent University, Technologiepark 927, B-9052 Ghent, Belgium. Tel: 003293313761; Fax: 003292217673; E-mail: geert.vanloo@irc.vib-ugent.be 
Diabetes Foundation, the Actions de Recherche Concertées (ARC)-ULB and the FNRS.

1. Mathis $D$ et al. Nature $2001 ; 414: 792-798$.

2. Eldor R et al. Proc Natl Acad Sci USA 2006; 103: 5072-5077.

3. Salem HH et al. Diabetes 2014; 63: 960-975.

4. Catrysse $\mathrm{L}$ et al. Trends Immunol 2014; 35: 22-31.

5. Liuwantara D et al. Diabetes 2006; 55: 2491-2501.

6. Grey ST et al. J Immunol 2003; 170: 6250-6256.

7. Hegazy DM et al. Genes Immun 2001; 2: 304-308.

8. Fung EY et al. Genes Immun 2009; 10: 188-191.
Cell Death and Disease is an open-access journal published by Nature Publishing Group. This work is licensed under a Creative Commons Attribution 4.0 International License. The images or other third party material in this article are included in the article's Creative Commons license, unless indicated otherwise in the credit line; if the material is not included under the Creative Commons license, users will need to obtain permission from the license holder to reproduce the material. To view a copy of this license, visit http://creativecommons.org/licenses/by/4.0/

Supplementary Information accompanies this paper on Cell Death and Disease website (http://www.nature.com/cddis) 